\title{
Распространенность пародонтопатогенных видов микроорганизмов у пациентов с клапанной патологией сердца
}

\author{
Мазур И. П. ${ }^{1}$, Витовский Р. М. ${ }^{2}$, Слободяник М. В. ${ }^{1}$, Мартыщенко И. В. ${ }^{2}$ \\ ${ }^{1}$ Национальная медицинская академия последипломного образования \\ имени П. Л. Шупика МЗ Украины (Киев) \\ 2 ГУ «Национальный институт сердечно-сосудистой хирургии имени Н. М. Амосова» (Киев)
}

\begin{abstract}
Пародонтопатогенные бактерии были обнаружены у пациентов с различными сердечно-сосудистыми заболеваниями. Это связано с наличием пародонтопатогенов в кровеносном русле.

Цель данного исследования - определить распространенность пародонтопатогенной микрофлоры в пародонтальных карманах (ПК) и на клапанах сердца у пациентов с приобретенными пороками сердца, требующими хирургического лечения (протезирование клапана сердца); на основе построения корреляционных плеяд определить особенности взаимоотношений между пародонтопатогенной микрофлорой.

Значительная распространенность заболеваний тканей пародонта (100\%) у пациентов с приобретенным пороком сердца вследствие транзиторной бактериемии привело к распространению представителей пародонтопатогенной микрофлоры на удаленных клапанах сердца. Выявление пародонтопатогенной микрофлоры на аортальном и митральном клапанах сердца может негативно влиять на течение заболевания сердца.
\end{abstract}

Ключевые слова: генерализованный пародонтит, клапанная патология сердца, ПЦР-реакция в реальном времени.

Взаимосвязь патологических процессов, развивающихся в различных органах и системах организма, остается одной из наиболее сложных и до конца не решенных проблем клинической медицины. Большинство исследователей признают тесную патогенетическую связь между воспалительными заболеваниями пародонта и общесоматической патологией. Результаты клинических и экспериментальных работ в этом направлении свидетельствуют, что существует этиопатогенетическая взаимосвязь генерализованного пародонтита с сердечно-сосудистыми заболеваниями (СС3) - такими, как ИБС, инфаркт миокарда (ИМ), стенокардия, артериальная гипертензия (АГ), заболевания периферических артерий и инсульт [5, 6, 8, 10, 11].

В настоящее время заболевания пародонта представляют собой сложную проблему, что связано прежде всего с высокой распространенностью и интенсивностью поражения тканей вокруг зуба. Наибольшей распространенностью среди воспалительных заболеваний пародонта отличается генерализованный пародонтит, который является дистрофически-воспалительным процессом, возникающим вследствие сочетанного воздействия различных экзо- и эндогенных факторов. Этиологические факторы болезней пародонта подразделяются на локальные и системные. К локальным относятся те, которые действуют непосредственно в тка- нях пародонта, тогда как системные зависят от общего состояния пациента. Ведущим локальным фактором этиопатогенеза считаются воспалительные реакции, спровоцированные специфическими бактериями зубного налета, которые находятся в микробной биопленке. Она представлена специализированной бактериальной экосистемой, которая окружена защитным матриксом, не позволяющим антибактериальным препаратам из слюны или десневой жидкости проникать вовнутрь микробной биопленки [8]. Поэтому микроорганизмы в бактериальной экосистеме более устойчивы к антибиотикам и антимикробным средствам [8]. Накопление биопленки способствует прогрессированию патологических процессов, образованию пародонтальных карманов [1].

Согласно современным данным, транзиторная бактериемия происходит не только во время проведения стоматологических манипуляций или чистки зубов, но и в момент жевания, что позволяет бактериям с кровотоком проникать в эндотелий сосудов, вызывая эндотелиальную дисфункцию, воспаление и атеросклероз [5]. Другой путь воздействия микрофлоры полости обусловлен стимулированием продукции медиаторов с атерогенным и провоспалительным системным эффектом (IL-1, IL-6, простагландин E2, фактор некроза опухоли - альфа) [7]. На основании этого Американ- 
ская ассоциация сердечно-сосудистых заболеваний (АНА) констатирует, что «пациентам с риском инфекционного эндокардита (ИЭ) следует установить и поддерживать удовлетворительное состояние здоровья органов полости рта, чтобы сократить потенциальные источники бактериальной диссеминации». Это обусловило практику назначения антибиотиков для профилактики эндокардита до проведения инвазивных стоматологических вмешательств.

Для идентификации пародонтопатогенной микрофлоры используют метод полимеразно-цепной реакции (ПЦР), позволяющий добиться значительного увеличения малых концентраций определенных фрагментов нуклеиновой кислоты (ДНК) в биологическом материале (пробе). Амплификация ДНК в ходе ПЦР позволяет обнаруживать в исследуемых образцах бактерии, присутствующие в ничтожном количестве. Кроме того, с помощью ПЦР можно провести всесторонний и детальный анализ ДНК, используя минимальный объем пробы [3].

Цель данного исследования - определить наличие пародонтопатогенной микрофлоры в пародонтальных карманах (ПК) и на клапанах сердца у пациентов с приобретенными пороками сердца, требующими хирургического лечения (протезирование клапана сердца); на основе построения корреляционных плеяд определить особенности взаимоотношений между пародонтопатогенной микрофлорой.

Материалы и методы исследования. В исследование включили пациентов, госпитализированных в Национальный институт сердечно-сосудистой хирургииимениН.М.Амосовавсвязиснеобходимостью протезирования сердца механическими клапанами. Проведено обследование 32 пациента в возрасте от 36 до 73 лет (Me=54,0, IQR: 44,0-59,75), находившихся на лечении с 2016 по 2017 год. Из них 69\% (22 чел.) имели диагноз митральная недостаточность, $31 \%$ (10 чел.) аортальная недостаточность.

Клиническое исследование проводили по общепринятым методикам. Тщательно собирали анамнестические данные: жалобы больного, кровоточивость во время чистки зубов, неприятный запах из ротовой полости, подвижность зубов, проводилось ли ранее лечение, какие лекарственные средства применялись. Особое внимание уделяли гигиеническому уходу за полостью рта, виду средств, которые применял пациент, регулярности проведения гигиенических мероприятий. Для определения взаимосвязи развития заболеваний пародонта с местными факторами и общими заболеваниями организма и более тщательного их анализа больному предлагали заполнить анкеты - вопросники стоматологического состояния здоровья (приложение А) и общего состояния здоровья (приложение Б).

Всем обследуемым пациентам проводили стоматологическое, пародонтологическое и рентгенологиче- ское исследование. Пародонтологическое исследование включало определение гигиенического состояния с определением индекса гигиены по Ю. А. Федорову и В. В. Володкиной. Клиническое исследование тканей пародонта предполагало определение отечности, кровоточивости, глубины пародонтальных карманов, уровня рецессии, клинического прикрепления десен. Глубину пародонтальных карманов оценивали в 6 точках, применяя пародонтальный зонд. Результаты всех измерений заносили в пародонтальную карту больного.

Для микробиологического исследования было собрано 60 образцов: 30 образцов содержимого пародонтальных карманов (5 мм и более) и 30 образцов биологического материала (митральный, аортальный клапаны сердца). Для изучения микробного пейзажа использовали тестовую систему «Стоматофлор» (регистрационное удостоверение в Украине № 12407/2013 от 15.02.2013), позволяющую проводить качественную и количественную оценку не только пяти основных пародонтопатогенов (Tannerella forsythus Bacteroides forsythus, Porphyromonas gingivalis, Aggregatibacter actinomycetemcomitans, Prevotella intermedia u Treponema denticola), но и наиболее часто встречаемого представителя грибковой микрофлоры - Candida albicans.

Необходимо отметить, что набор реагентов «Стоматофлор» включает: смесь для ПЦР-амплификации, специфичную для всех бактерий, что позволяет определять общую бактериальную массу; смеси, специфичные для микроорганизмов, и смесь для амплификации геномной ДНК человека (контроль взятия клинического материала - КВМ). КВМ используется для исключения ошибок преаналитического этапа. Кроме того, в наборе реагентов «Стоматофлор» в пробирки со смесями для амплификации добавлен внутренний контрольный образец (BK), предназначенный для оценки эффективности протекания полимеразной цепной реакции.

Программа клинического исследования соответствует требованиям, принятым международным сообществом, и действующим нормативно-правовым актам Украины: Постановлению КМУ от 09.11.2004 г. № 1497, приказу МО3 Украины от 03.08.2012 г. № 616 «Об утверждении правил проведения клинических исследований медицинской техники и изделий медицинского назначения и типового положения о комиссии по вопросам этики» и Государственной службы Украины по лекарственным средствам, Приказу М3 Украины № 690 от 23.09.09 г. с изменениями и дополнениями, внесенными Приказом МЗ № 523 от 12 июля 2012 г.

Исследования микрофлоры в пародонтальных карманах

Микробиологическое исследование содержимого пародонтальных карманов (ПК) проводили с помощью одноразового стерильного бумажного пина, по- 
сле чего он помещался в герметично закрытую пластиковую пробирку объемом 1,5 мл «Эппендорф» по одному пину в каждой пробирке. Материал доставляли в лабораторию в течение 6 часов.

\section{Исследование микрофлоры на клапанах сердца}

Забор материала клапанов сердца (22 митральных, 10 аортальных клапанов) производился во время операции с соблюдением всех правил асептики. Материал брался в одноразовые стерильные контейнеры из расчета «один клапан - один контейнер» для предотвращения контаминации. Если время от момента забора до доставки материала составляло больше 2 часов, то он сохранялся в холодильнике при температуре $6 \pm 2{ }^{\circ} \mathrm{C}$. Транспортная среда для биологического материала не использовалась. Такой метод был использован для того, чтобы исключить дополнительное (даже минимальное) разведение материала при проведении исследования. Каждая пробирка была промаркирована соответствующим образом и сопровождалась направлением с указанием необходимых данных.

Клапаны сердца измельчались на более мелкие фрагменты при помощи стерильных ножниц и пинцета, при этом для каждого нового образца брались отдельные наборы инструментов. Далее измельченные образцы заливали 1,0 мл стерильного $0,9 \%$ раствора натрия хлорида (физиологический раствор) с использованием стерильных одноразовых наконечников с аэрозольным фильтром, рекомендованных к применению в ПЦР-лабораториях. Пробирки оставляли на 20 минут при комнатной температуре для экстракции микробной массы в раствор. Через каждые 5 минут пробирки встряхивали в течение 10-15 сек. на вортексе для улучшения экстракции. После окончания экстракции пробирки центрифугировались на вортексе при 1000 об./мин. в течение 30 секунд для осаждения капель. Полученный экстракт в объеме 100 мкл вносился в отдельную промаркированную соответствующим образом пробирку типа «Эппендорф». В пробирки с экстрактом вносили по 300 мкл лизирующего раствора и далее выделяли нуклеиновые кислоты согласно инструкции по применению комплекта реагентов «Проба-НК».

\section{Подготовка праймера для ПЦР в реальном времени}

На этапе предобработки в каждую пробирку с бумажным пином вносили по 100 мкл стерильного 0,9\% раствора натрия хлорида (физиологический раствор) с использованием стерильных одноразовых наконечников с аэрозольным фильтром, рекомендованных к применению в ПЦР-лабораториях. Пробирки оставляли на 20 минут при комнатной температуре для экстракции микробной массы в раствор. Через каждые 5 минут пробирки встряхивали в течение $3-5$ секунд на вортексе для улучшения экстракции. После окончания экстракции пробирки центрифугировались на вортек- се при 1000 об./мин в течение 30 секунд для осаждения капель. После этого бумажный пин извлекали из пробирки стерильным пинцетом, тщательно отжимая о стенки избыток жидкости, и утилизировали в емкость с дезраствором. В пробирки с экстрактом вносили по 300 мкл лизирующего раствора и далее выделяли нуклеиновые кислоты согласно инструкции по применению комплекта реагентов «Проба-НК».

Для микробиологической диагностики современные лаборатории предлагают микроскопическое исследование, идентификацию микроорганизмов по культурально-морфологическим признакам (предварительно выращиваются микробные колонии), использование метода полимеразной цепной реакции (ПЦР). ПЦР позволяет точно установить наличие конкретного вида патогена с учетом праймеров, заложенных в диагностический набор. Полученные препараты нуклеиновых кислот передавали через передаточное окно в амплификационную, где проводили амплификацию согласно инструкции для набора реагентов для выявления условно-патогенных микроорганизмов полости рта методом ПЦР в режиме реального времени. После прохождения амплификации по показателю индикаторного цикла программно рассчитывали количество каждого из микроорганизмов (десятичный логарифм концентрации). Полученные значения позволяют оценить степень выраженности пародонтита (в материале из пародонтальных карманов) и наличие каких-либо парадонтопатогенов (в клапанах сердца). Интерпретация полученных результатов проводилась в соответствии с рекомендациями производителя.

Результаты исследования. Результаты проведенных клинических исследований выявили наличие заболеваний тканей пародонта у всех обследуемых пациентов (100\%). Из них у $31 \%$ (10 чел.) было зарегистрировано обострившееся течение генерализованного пародонтита, 69\% (22 чел.) обследуемых имели хроническое течение заболевания. Данные анамнеза пациентов свидетельствуют о систематическом приеме системных антибактериальных препаратов с целью профилактики инфекционного эндокардита, что обусловило превалирование хронического течения генерализованного пародонтита у обследуемого контингента. У $20 \%$ (6 чел.) обследуемых пациентов была диагностирована I степень тяжести генерализованного пародонтита, у $70 \%$ (22 чел.) - II степень, у 10\% (4 чел.) - III степень. Гигиеническое состояние у обследуемых пациентов оценивалось как плохое или очень плохое (индекс Федорова-Володкиной составил $3,9 \pm 1,01$ бала). Низкий уровень индивидуальной гигиены полости рта предопределил высокие показатели воспалительных процессов в тканях пародонта (индекс ПМА - 34,2 $\pm 5,1 \%$ ). Среднее значение индекса кровоточивости по Муллеману-Саксеру (PВI) составило 2,93 $\pm 0,27$. 
Результаты микробиологических исследований

Распространенность основных пародонтопатогенов в пародонтальных карманах. Результаты микробиологического исследования содержимого пародонтальныхкармановуобследуемыхпациентовсвидетельствует о высокой обсемененности пародонтопатогенами. У всех пациентов (100\%) было выявлено наличие Tannerella forsythia (Tf) в пародонтальных карманах. Наиболее высокая обсемененность была представлена такими пародонтопатогенами, как Porphyromonas gingivalis (Pg) - частота встречаемости составила 86,7\% (26 чел.), и Treponema denticola (Td) - 80,0\% (24 чел.). Проведенные результаты микробиологических исследований показали, что частота встречаемости в выборке пародонтопатогенного микроорганизма Prevotella intermedia (Pi) в пародонтальных карманах составила 40,0\% (12 чел.), a Aggregatibacter actinomycetemcomitan (Аа) в пародонтальных карманах обнаружен у $31 \%$ (10 чел.).

Частое применение системной антибактериальной терапии обусловило наличие грибковой флоры в содержимом пародонтальных карманов: Candida albicans (Ca) была зарегистрирована в пародонтальных карманах у 7 пациентов $(23,3 \%)$.

Микробный пейзаж на клапанах сердиа

Распространенность основных пародонтопатогенов на удаленных клапанах сердиа. Результаты микробиологических исследований показали высокий уровень обсемененности пародонтопатогенами митрального и аортального клапанов сердца. У большинства пациентов (18 чел., 60,0\%) с клапанной патологией сердца в биологическом материале (на удаленных клапанах сердца) был зарегистрирован пародонтопатогенный микроорганизм P. gingivalis $(\mathrm{Pg})$. Высокая степень обсемененности клапанов сердца была зарегистрирована пародонтопатогенами $T$. denticola (Td) - 40,0\% (12 чел.) и T. Forsythia (Tf) - 36,7\% (11 чел.). Реже выявляли на клапанах сердца такие пародонтопатогены, как $P$. intermedia $(\mathrm{Pi})$, который зарегистрировали у 10,0\% (3 чел.) обследуемых. У 3 пациентов (10,0\%) микроорганизм Aggregatibacter actinomycetemcomitan (Aа) был зарегистрирован на клапане при отсутствии в пародонтальных карманах. Грибковая флора Candida albicans (Ca) была зарегистрирована у двух пациентов на клапанах (6,7\%).

Корреляционный анализ микробного пейзажа содержимого пародонтальных карманов и клапанов сердиа

Нами была построена корреляционная матрица и вычислен коэффициент Спирмана, позволяющий выделить наиболее тесные связи между степенью заселенности пародонтопатогенами пародонтальных карманов и биологического материала. Наибольшее количество достоверных связей отмечено между обсемененностью такими пародонтопатогенами, как $P$. gingivalis -

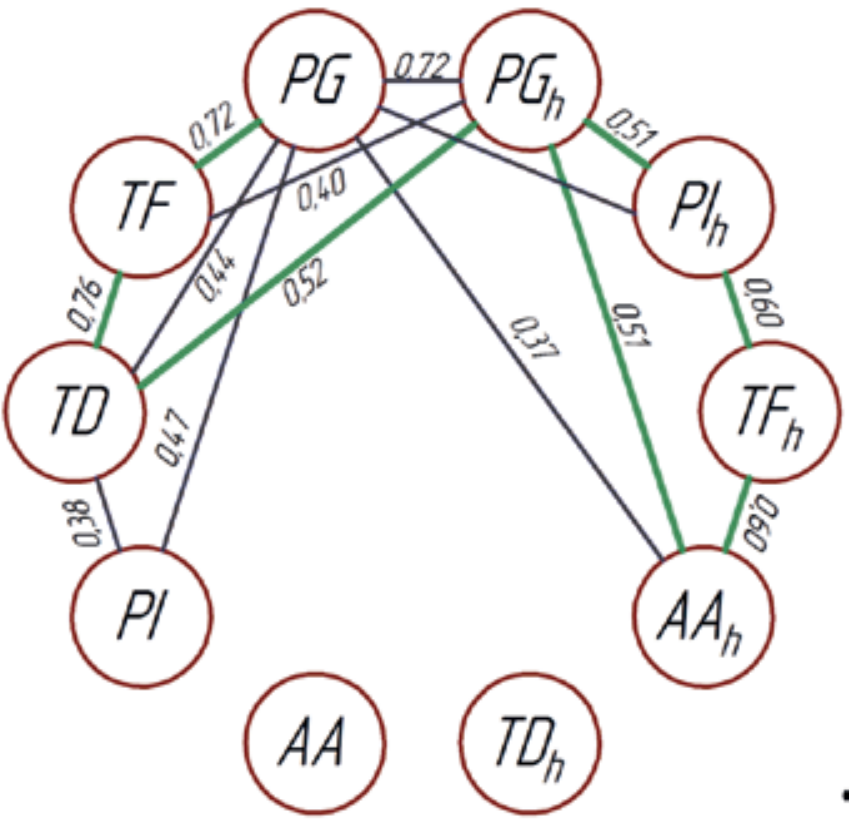

Рис. 1. Корреляционные плеяды внутрисистемных отношений межу пародонтопатогенной микрофлорой у пациентов с клапанной патологией. Candida albicans (Ca), Tannerella forsythia (Tf), Treponema denticola (Td), Prevotella intermedia (Pi) Aggregatibacter actinomycetemcomitan (Aa), Porphyromonas gingivalis $(\mathrm{Pg})$

P. intermedia $(\rho=0,47, \quad \mathrm{p}=0,006) ; \quad P$. gingivalis T. forsythensis $(\rho=0,72, \quad \mathrm{p}=0,001), \quad P$. gingivalis $T$. denticola $(\rho=0,47, \mathrm{p}=0,01)$, $P$. intermedia $-T$. denticola $(\rho=0,38, p=0,03), T$. forsythensis $-T$. denticola $(\rho=0,76$, $\mathrm{p}=0,001)$. Обращает на себя внимание, что обсемененность пародонтопатогеном A. actinomycetemcomitans не коррелирует с наличием других пародонтопатогенов: коэффициенты Спирмана для этого вида при сравнении с другими пародонтопатогенами не превышают 0,3 (рис. 1).

Полученные результаты микробиологического исследования продемонстрировали более высокую распространенность пародонтопатогенов в пародонтальных карманах у больных с клапанной патологией сердца. Статистически значимо выше $(\mathrm{p}<0,01)$ частота идентификации патогенной микрофлоры Tannerella forsythia $(100 \pm 11,4 \%)$, Porphyromonas gingivalis $(86,7 \pm 12,4 \%)$, Tannerella forsythia $(80,0 \pm 15,4 \%)$. Высокий уровень обсемененности данными пародонтопатогенами обуславливает и большую частоту распространенности этих пародонтопатогенов на клапанах сердца у больных с клапанной патологией сердца. Полученные результаты исследования свидетельствуют о высокой статистически значимой зависимости наличия патогенной микрофлоры в биологическом материале (удаленные клапаны сердца) от ее наличия в пародонтальных карманах: Pg $(60,0 \pm 17,8 \%$, p<0,01), 
T. forsythia (Tf) (36,7\% обследованных), T. denticola $(\mathrm{Td})$ $(26,7 \%),(\mathrm{p}<0,05)$.

Изучение взаимосвязей между полученными показателями проводилось методом построения корреляционных плеяд по алгоритму Терентьева, которые представляют собой сгустки однородных зависимостей. В группе обследованных пациентов с клапанной патологией установлены достоверные связи в основном между такими представителями пародонтопатогенной микрофлоры, как $P$. Gingivalis $-P$. intermedia $(\rho=0,47, \quad \mathrm{p}=0,006) ; \quad P$. Gingivalis $-T$. forsythensis $(\rho=0,72, p=0,001) ; P$. Gingivalis $-T$. denticola $(\rho=0,47$, $\mathrm{p}=0,01) ; P$. Intermedia $-T$. denticola $(\rho=0,38, \mathrm{p}=0,03)$; $T$. forsythensis $-T$. denticola $(\rho=0,76, p=0,001)$. У пациентов с клапанной патологией отмечена отрицательная взаимосвязь между пародонтопатогенным микроорганизмом Aggregatibacter actinomycetemcomitan (Aa) и другими представителями микрофлоры, коэффициенты Спирмана для этого вида при сравнении с другими пародонтопатогенами не превышают 0,3 .

Выводы. Таким образом, проведенные результаты исследования продемонстрировали высокую распространенность генерализованного пародонтита у пациентов с клапанной патологией. Практически все пациенты из группы обследования ранее принимали системные антибактериальные препараты, что значительно снижало частоту встречаемости обострившегося течения генерализованного пародонтита.

Результаты микробиологического исследование с применением ПЦР-тестирования содержимого пародонтальных карманов и биологического материала (удаленные клапаны сердца) продемонстрировали, что пародонтопатогенный микроорганизм $P$. gingivalis имеет наибольшую распространенность - как в пародонтальных карманах $-86,7 \pm 12,4 \%$, так и на клапанах сердца $-60,0 \pm 17,8 \%(\mathrm{p}<0,01)$. В результате повреждения слизистой оболочки полости рта возникает путь перемещения основных пародонтопатогенов с последующей их колонизацией на поверхности клапанов сердца.

Высокая контаминация органов и тканей таким пародонтопатогеном, как P. gingivalis, связана с особенностями самого микроорганизма: наличие фимбрий обеспечивает данному виду микрофлоры высокую адгезию к эпителию десны и эндотелию сосудов; более толстая в сравнении с другими микроорганизмами капсула позволяет быть устойчивой к фагоцитозу лейкоцитами. По данным литературы, P. gingivalis наиболее часто связывают с другой сердечно-сосудистой патологией - ишемической болезнью сердца. Этот микроорганизм был идентифицирован с высокой частотой на атероматозных бляшках кровеносных сосудов in vitro и in vivo [5, 8]. Установлено, что бактерии P. gingivalis, P. intermedia [12] могут проникать и персистировать внутри эндотелиальных клеток аорты in vitro. При этом, как показали исследования, P. gingivalis проявляет способность к внутриклеточному реплицированию внутри аутофагосомы. Способность $P$. gingivalis, как и других пародонтопатогенных бактерий, к внутриклеточному персистированию может инициировать развитие вторичной хронической инфекции.

\section{Литература}

1. Мазур И. П., Слободянник М. В. Системные антибактериальные препараты в пародонтологии // Современная стоматология. - 2017. - № 1. - С. 18-22.

2. Витовский Р. М., Мазур И. П., Слободяник М. В. Микробиомы пародонтальных карманов и биологического материала у пациентов с генерализованным пародонтитом и клапанной патологией сердца // Стоматология Эстетика Инновации. - 2018. - № 2. - С. 185-201.

3. Мазур І. П., Харченко Н. Л. Мікробіологічний моніторинг транзиторної бактеріємії у стоматологічних хворих // Дентальні технології. - 2010. - № 1 (44). C. $10-13$.

4. Periodontal pathogens in atheromatous plaques. A controlled clinical and laboratory trial / Aquino AR., Lima KC, Paiva MS, Rфзаs IN, Siqueira JF Jr. // J. Periodontal Res. - 2011. - Vol. 46 (3). - P. 303-309.

5. Etiology of valvular heart disease in the 21st century / Konstantinos Dean Boudoulas, Jeffrey S. Borer, Harisios Boudoulas // J Cardiology. - 2013. - Vol. 126. - P. 139-152.

6. Ghazal Aarabi, Guido Heydecke and Udo Seedorf. Roles of Oral Infections in the Pathomechanism of Atherosclerosis // International Journal of Molecular Sciences. - 2018. - Vol. 19 (7).

7. Francisco Artur Forte Oliveira, DDS, MSc, Clarissa Pessoa Fernandes Forte, DDS, MSc. Molecular Analysis of Oral Bacteria in Heart Valve of Patients With Cardiovascular Disease by Real-Time Polymerase Chain Reaction // Medicine. - 2015. - Vol. 47. - P. 1-5.

8. Identification of periodontal pathogens in atheromatous plaques / Haraszthy VI, Zambon JJ, Trevisan M et al. // J. Periodontol. - 2012. - Vol. 71. - P. 1554-1560.

9. Hajishengallis G, Lamont RJ. Beyond the red complex and into more complexity: the polymicrobial synergy and dysbiosis (PSD) model of periodontal disease etiology // Oral Microbiol. -2012. - Vol. 27. - P. 409-419.

10. Periodontal disease and coronary heart disease incidence: a systematic review and meta-analysis / Humphrey L.L., Fu R., Buckley D.I. et al. // J. Gen. Intern.Med. - 2012. Vol. 23. - P. 2079-2086.

11. Role of Systemic Markers in Periodontal Diseases:APossible Inflammatory Burden and Risk Factor for Cardiovascular Diseases? / L Sravya, S Warad, K Vijayalaxmi, P Sejal and DJ Hazeil // Ann Med Health Sci Res. - 2014. - Vol. 4 (3). - P. 388-392.

12. Periodontal bacterial invasion and infection: contribution to atherosclerotic pathology / Reyes L, Herrera D, Kozarov E, Roldan S, Progulske-Fox A // J Clin Periodontol. 2013. - Vol. 40. - P. 30-50.

13. The Merck Manual. Руководство по медицине. Диагностика и лечение / гл. ред. Марк Х. Бирс; пер. с англ. под ред. А. Г. Чучалин. - Литтерра, 2011. - 3695 с. 


\title{
Prevalence of parodontopathogenic microflora in patients with valvular pathology of the cardiovascular system
}

\author{
Mazur I. P. ${ }^{1}$, Vitovsky R. M. ${ }^{2}$, Slobodyanyk M. V. ${ }^{1}$, Martyshchenko I. V. ${ }^{2}$ \\ ${ }^{1}$ Shupyk P. L. National Medical Academy of Postgraduate Education
}

2 National M.M. Amosov Institute of Cardiovascular Surgery National Academy of Medical Sciences of Ukraine

Parodontopathogenic bacteria were found in patients with various cardiovascular diseases, including atherosclerosis, atherosclerotic aneurysms, diseases of peripheral arteries, coronary heart disease, valvular endocarditis. This is due to the presence of periodontal pathogens in the bloodstream.

The purpose of this study is to determine the prevalence of periodontal pathogenic microflora in the periodontal pockets (PC) and on the heart valves in patients with acquired heart defects requiring surgical treatment (prosthetic heart valve). Based on the construction of correlation pleiades, determine the features of the relationship between the periodontal pathogenic microflora.

Material and research methods. For clinical and microbiological studies, 32 patients with acquired heart defects (mean age 52.4 \pm 11.1 years) were examined who underwent surgical treatment at the National Institute of Cardiovascular Surgery them N. M. Amosov. Dental, periodontal, X-ray and microbiological examinations were performed. A microbiological study of the main periodontopathogens (PCR-diagnosis) was performed in the contents of the periodontal pockets (32 samples) and the biological material - the mitral, aortic valve of the heart (32 samples) removed during surgical treatment.

The results of the study. Using a microbiological study (PCR-real-time reaction), all of the periodontal pathogenic microflora were found on the remote heart valve (biological material). The highest prevalence in both biological material $(60 \%)$ and in the periodontal pocket $(86.7 \%)$ was registered for the periodontopathogenic bacterium Porphyromonas gingivalis. A lower prevalence in biological material was found in T. denticola (40.0\%); T. Forsythia (36.7\%); P. Intermedia $(10.0 \%)$ and Aggregatibacter actinomycetemcomitan (10\%). Using the method of full correlation analysis with the inclusion of linear and nonlinear correlation and correlation relational algorithms, the following relationships between the periodontal pathogenic microflora are obtained: P. gingivalis - P. Intermedia $(\rho=0.47, p=0.006)$; P. gingivalis - T. forsythensis $(\rho=0.72$, $p=0.001)$, P. gingivalis - T. denticola $(\rho=0.47, p=0.01)$, P. intermedia - T. denticola $(\rho=0.38, p=0.03)$, T. forsythensis T. denticola $(\rho=0.76, p=0.001)$. The periodontopathogenic microorganism Aggregatibacter actinomycetemcomitan (Aa) does not correlate with other representatives of the periodontal pathogenic microflora $(\mathrm{p}=0.3)$.

Findings. A significant prevalence of periodontal tissue diseases (100\%) in patients with acquired heart disease, due to transient bacteremia, led to the spread of representatives of the periodontal pathogenic microflora at the remote heart valves.

Detection of periodontal pathogenic microflora on the aortic and mitral valves of the heart can adversely affect the course of heart disease.

Key words: generalized periodontitis, valvular heart disease, PCR-real-time reaction.

\section{Поширеність пародонтопатогенних видів мікроорганізмів у пацієнтів із клапанною патологією серця}

\author{
Мазур І. П. ${ }^{1}$, Вітовський Р. М. ${ }^{2}$, Слободяник М. В. ${ }^{1}$, Мартищенко І. В. ${ }^{2}$ \\ ${ }^{1}$ Національна медична академія післядипломної освіти імені П. Л. Шупика МОЗ України (Київ) \\ 2 ДУ «Національний інститут серцево-судинної хірургії імені М. М. Амосова НАМН України» (Київ)
}

Пародонтопатогенні бактерії були виявлені у пацієнтів із різними серцево-судинними захворюваннями, в тому числі атеросклерозом, атеросклеротичними аневризмами, захворюваннями периферичних артерій, ішемічною хворобою серця, клапанними ендокардитами. Це пов'язано з наявністю пародонтопатогенів у кровоносному руслі.

Мета даного дослідження - визначити поширеність пародонтопатогенної мікрофлори в пародонтальних кишенях (ПК) і на клапанах серця у пацієнтів із набутими вадами серця, які потребують хірургічного лікування (протезування клапана серця); на основі побудови кореляційних плеяд визначити особливості взаємовідносин між пародонтопатогенною мікрофлорою.

Матеріали та методи дослідження. Для проведення клініко-мікробіологічних досліджень було обстежено 32 пацієнти з набутими вадами серця (середній вік $52,4 \pm 11,1$ року), що проходили хірургічне лікування в Національному інституті серцево-судинної хірургії імені М. М. Амосова. Проведено стоматологічне, пародонтологічне, рентгенологічне і мікробіологічне дослідження. Мікробіологічне дослідження на представників основної пародонтопатогенної мікрофлори (ПЛР-діагностика) проводили у вмісті пародонтальних ктшень (32 зразки) і біологічному матеріалі - мітральний, аортальний клапани серця (32 зразки), вилученому під час оперативного втручання.

Результати дослідження. За допомогою мікробіологічного дослідження (ПЛР-реакція в реальному часі) були виявлені всі представники пародонтопатогенної мікрофлори на видаленому клапані серця (біологічний матері- 
ал). Найбільша поширеність як у біологічному матеріалі (60\%), так і в пародонтальній кишені $(86,7 \%)$ була зареєстрована для пародонтопатогенної бактерії Porphyromonas gingivalis. Менша поширеність у біологічному матеріалі виявлена у T. denticola (40,0\%), T. forsythia (36,7\%), P. intermedia (10,0\%) і Aggregatibacter actinomycetemcomitan (10\%). За допомогою методу повного кореляційного аналізу із включенням алгоритмів лінійної та нелінійної кореляції та кореляційних відносин отримані такі взаємовідносини між пародонтопатогенною мікрофлорою: P. gingivalis P. intermedia $(\rho=0,47, \mathrm{p}=0,006) ;$. gingivalis $-T$. forsythensis $(\rho=0,72, \mathrm{p}=0,001), P$. gingivalis $-T$. denticola $(\rho=0,47$, $\mathrm{p}=0,01)$, $P$. intermedia $-T$. denticola $(\rho=0,38, \mathrm{p}=0,03)$, T. forsythensis $-T$. denticola $(\rho=0,76, \mathrm{p}=0,001)$. Пародонтопатогенний мікроорганізм Aggregatibacter actinomycetemcomitan (Aa) не корелює з іншими представниками пародонтопатогенної мікрофлори ( $\mathrm{p}=0,3)$.

Висновки. Значна поширеність захворювань тканин пародонта (100\%) у пацієнтів із набутою вадою серця внаслідок транзиторної бактеріємії призвела до поширення представників пародонтопатогенної мікрофлори на видалених клапанах серця. Виявлення пародонтопатогенної мікрофлори на аортальному та мітральному клапанах серця може негативно впливати на перебіг захворювання серця.

Ключові слова: генералізований пародонтит, клапанна патологія серия, ПЛР-реакція в реальному часі. 